\title{
8.11 Педагогічні умови формування самооцінки молодших школярів в освітній діяльності
}

Стаття $є$ теоретико-експериментальним дослідженням проблеми формування самооцінки молодших школярів у процесі навчання.

На основі вивчення й аналізу філософської і психолого-педагогічної літератури, здійснено системний аналіз теорії та практики формування самооцінки молодших школярів в освітній діяльності та визначено дидактичні умови, що сприяють ефективності цього процесу: мотивація учнів до самооцінної діяльності; включення педагогом учнів до систематичного i послідовного процесу самоаналізу в умовах спільної навчальної діяльності; поетапність формування мотиваційно-ціннісного, когнітивного та діяльніснопрактичного компонентів самооцінки; опора на традиції гуманістичної освіти, формування гуманних взаємин між учасниками освітнього процесу, підтримка позитивного емоційного стану молодших школярів у процесі самооцінювання навчальної діяльності, надання їм своєчасної допомоги.

У роботі узагальнено сутність поняття «самооцінка», іiі структуру, функції та особливості формування у процесі навчання; окреслено можливості спільної навчальної діяльності у формуванні самооцінки молодших школярів.

У дослідженні здобуто нові дані про зміни, що відбуваються в самооцінці молодших школярів під впливом систематичного введення у процес спільної навчальної роботи визначених дидактичних умов, доведено їх ефективність.

Ключові слова: педагогічні умови, самооцінка, молодші школярі, навчальна діяльність, мотиваційно-ціннісний, когнітивний, діяльніснопрактичний компоненти, спільна навчальна діяльність.

\footnotetext{
Комар О.А., Дячук П.В., Роенко Л.М. Педагогические условия формирования самооценки младших школьников в учебной деятельности

Статья содержит теоретико-экспериментальное исследование проблемы формирования самооценки младших школьников в процессе обучения.
} 
На основе анализа теоретических источников рассмотрена сущность и структура самооценки как составляющей учебно-познавательной деятельности учащихся, ее функции, определены дидактические условия формирования самооценки школьников в совместной учебной деятельности с учетом особенностей учащихся младшего школьного возраста и возможностей коллективной формы обучения.

Установлено, что самооценка детерминирует направление и уровень активности субъекта, становление его ценностных ориентаций, личностных смыслов и, в конечном итоге, «вершину» его достижений. Самооценка является важным психологическим фактором формирования учебной деятельности учащихся, играет важную роль в становлении их индивидуальных особенностей и возрастных характеристик. Выделены функции самооценки в развитии личности: мотивационная, ориентационная, регулятивная, рефлексивная и ее структурные компоненты: мотивационно-ценностный, когнитивный, деятельностно-практический.

На основании структурного построения учебной деятельности, характеризующейся органичным сочетанием трех составляющих ее блоков (частей) - информационно-ориентационного, операционно-исполнительного и контрольно-оценочного - показаны возможности всех этапов урока по формированию самооценки младших школьников.

Доказано, что использование совместных форм учебной деятельности вносит существенные позитивные изменения в формирование такого личностного образования, как самооценка, создает условия для коллективного анализа работы, развития умений и потребностей анализировать, доказывать свое мнение, оценивать свои действия с точки зрения других. Выяснено, что совместной считается деятельность, при которой ее задачи воспринимаются как групповые, нуждаются в кооперации при их решении. Другим признаком совместной работы является наличие взаимной зависимости при выполнении работы, взаимного контроля и ответственности. 
Рассмотрение вопросов исследования органически связано с определяющим вектором модернизации современной школы - направленности на общее развитие школьников в учебно-воспитательном процессе, на предоставлении каждому ученику оптимальных возможностей в личностном становлении, в расширении возможностей самореализации и раскрытии индивидуальных способностей. В непосредственном соотнесении с этой направленностью в исследовании в процесс формирования самооценки школьника заложен принцип личностно-ориентированного подхода к ребенку, утверждающий признание его уникальности, неповторимости, самоценности, и принцип педагогического оптимизма - высокого уровня ожиданий по отношению к ребенку, веры в его силы и возможности.

В исследовании доказывается, что процесс формирования адекватной самооценки учебной деятельности у младших школьников требует соблюдения следующих дидактических условий: мотивации учащихся к самооценочной деятельности; включение педагогом учащихся в систематический и последовательный процесс самоанализа в условиях совместной учебной деятельности; поэтапность формирования когнитивного, мотивационноценностного и деятельностно-практического компонентов самооценки; опора на традиции гуманистического образования, формирование гуманных взаимоотношений между участниками учебного процесса, поддержка положительного эмоционального состояния младших школьников в процессе самооценки учебной деятельности, оказания им своевременной помощи при анализе и оценке учебной деятельности в различных формах: совет, консультация, корректировка.

Экспериментальная работа представлена двумя последовательными этапами. На первом этапе формирующего эксперимента решались задачи: стимулирование желания оценивать себя, свою деятельность на уроке, формирование умений оценивать свою деятельность по «эталонам». В этот период ученики усвоили «эталоны», по которым можно адекватно оценить себя, оценочные критерии. Задачами второго этапа формирующего эксперимента 
было: закрепить полученные знания и умения в оценке и самооценке младших школьников, включить детей в совместную учебную деятельность, ознакомить учащихся с новой формой организации совместной учебной деятельности кооперативной, и выявить ее возможности в развитии самооценки.

В ходе эксперимента доказано, что учебная деятельность, построенная с соблюдением предложенных дидактических условий, способствует развитию адекватной самооценки младших школьников, что подтверждается положительными показателями в развитии ее когнитивного, мотивационноценностного и деятельностно-практического компонентов.

Ключевые слова: педагогические условия, самооценка, младшие школьники, учебная деятельность, мотивационно-ценностный, когнитивный, деятельностно-практический компоненты, кооперативная учебная деятельность.

Komap O., Dyachuk P. Roienko L. The didactic conditions of selfassessment of junior high school students in the training activities.

The thesis is dedicated to the theoretical grounds and experimental checks of the didactic conditions of junior high school students' self-assessment in the training activities.

On the basis of an analysis of theoretical sources, the essence of self-assessment, its functions, types and forms of organization in the teaching process are considered, ways of forming junior high school students' self-assessment in generic training are determined.

The usefulness of any lesson's stages on the junior high school students' selfassessment formation having specially organized work is shown.

The Didactic Conditions of junior high school students' self-assessment, under which primary schoolchildren have a real opportunity to train self-assessment activity, to learn different approaches to self-assessment skills are justified and experimentally proved. 
It is proved that the use of training general forms introduces substantial positive modifications to self-assessment formation, promotes the increase of the level of structural components: motivational, cognitive, practical, each of which includes phases of design, organization, regulation and correction.

Keywords: the didactic conditions, self-assessment, junior high school students, training activities, the motivational, cognitive, practical components, cooperative form of training.

Актуальність теми. Нова концепція початкової освіти, поряд 3 виконанням традиційних завдань, зобов'язує школу створити умови для різнобічного розвитку особистості дитини, іiі самоствердження та творчої самореалізації, формування людини з новим рівнем свідомості, яка володітиме новим мисленням, високою культурою життєвого самовизначення. Водночас усвідомлюватиме себе індивідуальністю, членом суспільства і представником людства. Така людина спроможна самостійно формувати цілі, знаходити оптимальні шляхи їх досягнення, брати на себе відповідальність за свої вчинки й діяльність, здатна до оцінки й самооцінки.

Новий Державний стандарт початкової загальної освіти (2018) зумовлює побудову навчання в початковій школі на засадах особистісно-орієнтованого, компетентнісно-діяльнісного підходів. Метою освіти стає загальнокультурний, пізнавальний i особистісний розвиток учнів, що забезпечує формування ключових компетентностей, і зокрема, такої ключової компетенції, як уміння вчитися, здатність до саморозвитку та самовдосконалення. Останнє вимагає сформованості у дитини уявлення про себе і свої можливості, вміння всебічно та об'єктивно оцінювати особливості своєї особистості і діяльності, приймати роль учня, правильно вибудовувати свої взаємини з оточенням. Тобто, йдеться про певний рівень сформованості самооцінки. Саме тому педагоги покликані не лише збагачувати учнів певним обсягом знань, способами дій, а й формувати в них критичне ставлення до своїх можливостей, успіхів, навички самооцінки у 
навчально-виховному процесі, що стає можливим за їх систематичного та цілеспрямованого формування.

Теоретичний аналіз психолого-педагогічної літератури показує, що в науці накопичено певні знання про сутність самооцінки і способи формування іiі у школярів.

Проблемі самооцінки присвячено численні дослідження зарубіжних учених (Р. Бернс [678], 3. Фройд [710], С. Фромм [711] та ін.).

Дослідники М. Андреєва [674], Л. Виготський [680], I. Кон [692], О. Леонтьєв [696], В. Столін [708], І. Чеснокова [713] та інші у своїх роботах розглядають самооцінку як внутрішнє ядро особистості, як їі свідомий початок, як згусток індивідуальної самосвідомості, як систему уявлень про себе.

Самооцінці як особистісному утворенню відводиться центральне місце в загальному контексті формування особистості, іiі можливостей, здібностей, спрямованості, активності, суспільної значущості (Г. Ліпкіна [697], М. Матюхина [700], Н. Пеньковська [702]). Дослідженню структури самооцінки, іiі форм, особливостей формування в онтогенезі присвячено роботи Т. Галкиної [681], П. Сресько [684], А. Захарової [686], І. Загурської [685]. Науковцями простежено динаміку самооцінки суб'єкта (О. Белобрикіна [677], С. Гончаренко [682], М. Казакина [689], А. Ларіна [694], М. Ярмаченко [715]. Також вивчаються функціональні зв'язки самооцінки із загальним процесом формування особистості школяра (І. Зязюн [688], Я. Коломинський [704], В. Рубцов [705]). Показано значення самооцінки у міжособистісному спілкуванні (Т. Каракуліна [691], О. Леонов [695], Н. Ліфарева [698]).

Низка досліджень самооцінки в освітній діяльності пов’язуються 3 вивченням самооцінної мотивації, зі співвідношенням особистісної і навчальної самооцінки, із взаємозв’язком самооцінки та рівнем домагань (О. Савченко [706], Г. Цукерман [712]), формуванню самооцінки в учнів (А .Захарова [687], Г. Ліпкіна [697], Т. Токарська [709], I. Чеснокова [713], В. Шапар [714]), 3 особливостями формування самооцінки в умовах 
міжособистісного спілкування (Г. Костюк [693], Н. Шевченко [707]), зі шляхами формування самооцінки в умовах навчальної діяльності.

Здійснений аналіз науково-методичних праць 3 проблеми формування самооцінки свідчить, що здебільшого увага акцентується на процесі виховання. Самооцінка розглядається багатьма науковцями як розуміння людиною своїх якостей, властивостей, а поза увагою дослідників залишається сам процес самооцінювання, у якому виникає, перевіряється, доповнюється уявлення дитини про себе.

У дослідженнях К. Бардіна [675], Л. Божович [679], Г. Ліпкіної [697], Г. Цукерман [712] переконливо показано, що сенситивним періодом для становлення самооцінки як особливого компонента самосвідомості є молодший шкільний вік. Основні досягнення цього віку обумовлені провідним характером навчальної діяльності, тож починати формувати адекватну, критичну самооцінку слід саме в початкових класах, у процесі навчальної діяльності молодших школярів, створюючи сприятливі умови, за яких діти стають у самооцінці самостійними.

Особливі функції у формуванні самооцінки учня відіграє навчальна співпраця. Це сприяє розвиткові у школяра потреби і здатності оцінювати i порівнювати себе з іншими. Завдяки цьому створюються умови, що оптимізують становлення позитивних характеристик самооцінки. У ході спільної навчальної роботи самооцінка учнів набуває більш виражену рефлексійність, критичність $\mathrm{i}$ обгрунтованість, що досягається зверненням дитини до аналізу своєї діяльності, iï процесу та результатів. Зміни в самооцінці пов'язані з усвідомленням учнями тих якостей своєї особистості, які забезпечують продуктивність навчальної роботи та іiі комунікативний характер. Визначальним моментом позитивних зрушень в самооцінці виступає зростання у дитини вимогливості до себе та доброзичливого ставлення до однолітків.

У результаті аналізу педагогічного досвіду загальноосвітніх навчальних закладів з формування самооцінки молодших школярів нами виявлено низку суперечностей між: 
- соціальною та особистісною значущістю формування самооцінки i низьким рівнем іiї сформованості у молодших школярів;

- необхідністю формувати самооцінку молодших школярів у процесі навчання і слабкою підготовленістю вчителів до керівництва цією діяльністю;

- потребою педагогів в опануванні технологіями формування самооцінки молодших школярів у навчальній діяльності та недостатнім їх відображенням у психолого-педагогічній і методичній літературі;

- значним потенціалом спільної навчальної діяльності та недостатнім іiї використанням при формуванні адекватної самооцінки молодших школярів.

Отже, актуальність дослідження зумовлена:

- соціальним замовленням суспільства на виховання майбутніх громадян, які здатні об’єктивно контролювати, оцінювати й коригувати свою діяльність;

- потребою визначення ефективних педагогічних технологій, спрямованих на формування самооцінки молодших школярів;

- необхідністю створення сприятливих умов задля формування самооцінки молодших школярів у навчальній діяльності.

Метою дослідження $\epsilon$ визначення й теоретичне обгрунтування педагогічних умов, що сприяють формуванню самооцінки молодших школярів у процесі навчання.

Для розуміння сутності самооцінки нами було проаналізовано іï трактування у філософському, психологічному і педагогічному аспектах. 3 аналізу філософських праць 3 проблеми самооцінки (Геракліт, Демокрит, Антифон, Антисфен, Плутарх, Платон, Аврелій М., Леонардо да Вінчі, Декарт Р., Локк Д., Юм Д., Кант І., Гегель та ін.) можна зробити висновок, що і в минулому, і сьогодні питання пізнання людиною самої себе викликають інтерес у рамках філософії освіти, дидактики і педагогічної практики. У працях педагогів і психологів (Б. Ананьєв, С. Батутіна, Р. Бернс, Л. Божович, Л. Виготський, М. Захарова, I. Кон, Г. Ліпкіна, С. Рубінштейн, В. Столін, І. Чеснокова, Г. Цукерман) самооцінка характеризується як основа процесу самоусвідомлення, показник індивідуального рівня розвитку, його особистісний аспект. Самооцінка 
як особистісне утворення бере участь у регуляції поведінки і діяльності, а як

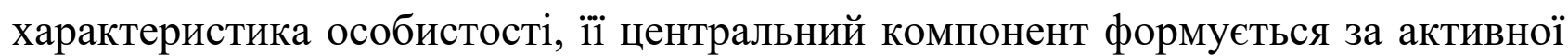
участі самої особистості і відображає своєрідність иї внутрішнього світу.

Виходячи зі змістового аналізу наукових джерел, ми послуговуємося трактуванням самооцінки як оцінювання особистістю себе, своїх можливостей, свого місця серед інших людей. Водночас аналіз підходів до визначення поняття «самооцінка» та численні його інтерпретації (Л. Бороздіна, М. Боцманова, Л. Виготський, А. Захарова, Г. Катрич, О. Леонтьєв, О. Молчанова) дали підстави розглядати ii як чинник навчально-пізнавальної діяльності учня, що становить складний рефлексійно-аналітичний процес, який є цілеспрямованим, внутрішньо мотивованим, структурованим і корегованим під час його здійснення та отримання результату, що зумовлюється дидактичними умовами, психологічними та особистісними особливостями учня як суб’єкта навчання, у якому виникає, перевіряється, доповнюється уявлення дитини про себе.

Огляд психолого-педагогічної літератури (Р. Бернс, О. Белобрикіна, Л. Божович, А. Дусавицький, О. Леонтьєв, Л. Поміткіна, С. Рубінштейн, Т. Токарська, І. Чеснокова, П. Якобсон) виявив неодностайність у поглядах на структурні компоненти самооцінки.

Здійснений теоретичний аналіз дав змогу нам подати структуру самооцінки у вигляді трьох компонентів: когнітивного, основу якого складають знання людини про себе - ситуативні чи стійкі, позитивні чи негативні, більш чи менш значущі для особистості; мотиваціийно-ц̧іннісного, що характеризується позитивним ставленням до дії самооцінювання, потребою довідатися про себе, свої позитивні і негативні характеристики, прагненням досягти успіху у спільній діяльності, пізнавати себе з кращої сторони; діяльнісно-практичного, який містить систему умінь самооцінювання, характеризується здатністю розрізняти ознаки, за якими діти оцінюють свої позитивні і негативні якості, діяльність у групі, уміння адекватно оцінити власну діяльність у групі, здатність критично ставитися до оцінки своїх умінь іншими учнями. 
У межах проблематики дослідження розглянуто функції самооцінки (Л. Виготский [680], В. Зинченко [690], Т. Каракуліна [691], К. Островська [701], Н. Пеньковська [702], О. Савченко [706]). На підставі здійсненого аналізу психолого-педагогічних наукових джерел ми виокремили такі функції самооцінки: мотиваційну, що забезпечує свідому, мотивовану поведінку, реалізацію обраної позиції, самореалізацію і містить всі види спонукань мотиви, прагнення, ідеали, цілі, усвідомлені спонукання до діяльності; орієнтаційну, яка передбачає орієнтування в ситуаціях оцінювання себе, своїх можливостей, своєї діяльності в групі; регулятивну, що забезпечує свідому саморегуляцію своєї поведінки за умов, які вимагають докладання свідомих зусиль для оцінювання себе і виконуваної діяльності, керування собою в умовах емоційного збудження чи втоми, здатність діяти відповідно до вимог ситуації, дорослого чи дитячого колективу; рефлексійну, яка виявляється в умінні людини усвідомлювати те, що вона робить, і аргументувати, обгрунтовувати свою діяльність.

Дослідження педагогів і психологів характеризують молодший шкільний вік як сенситивний для формування самооцінки, оскільки у цей віковий період відбуваються кардинальні зміни всіх ї̈ структурних компонентів, удосконалюється діяльність самооцінювання. До кінця молодшого шкільного віку самооцінка нерідко виступає домінувальним мотивом поведінки i діяльності. Це пов'язано зі зростанням пізнавальних можливостей дитини, посиленням інтересу до себе і схильності до самоспостереження.

Масова шкільна практика підтверджує відсутність цілеспрямованого досвіду формування у молодших школярів самооцінки у навчальній діяльності. Дослідження, які були проведені у школах Черкащини, показали, що у 55,2\% учнів рефлексійні уміння знаходяться на початковому рівні, у 34,9\% - на середньому, і тільки у 9,9\% - на високому. Самооцінка складається переважно стихійно, поза цілеспрямованим впливом з боку вчителя. Одна з причин цього, на нашу думку, - відсутність системних знань про природу самооцінки, умови, закономірності іï формування і розвитку. 
Аналіз психологічних і педагогічних досліджень дав змогу зробити припущення про значні можливості навчальної діяльності у формуванні самооцінки молодших школярів. У рамках концепції особистісно-орієнтованого, компетентнісно-діяльнісного підходів до навчання, у руслі якого виконане дослідження, важливу роль відіграє спільна (групова, колективна, кооперативна, спільно-розподільча) навчальна діяльність учнів, методологічні, філософські, соціально-психологічні аспекти якої знайшли висвітлення у працях Н. Бібік, О. Біди, В. Кузя, О. Комар, О. Коберника, Г. Коберник, М. Марусинець, I. Осадченко, Л. Пироженко, О. Пометун та ін.

Спільною вважається діяльність, за якої ії задачі сприймаються як групові і потребують кооперації у процесі розв'язання. Іншою ознакою спільної навчальної діяльності $є$ наявність взаємозалежності при виконанні робіт, що вимагають розподілу обов'язків, взаємного контролю.

Аналіз літератури, пов’язаної з вивченням спільної навчальної діяльності і iï впливом на формування адекватної самооцінки, свідчить про те, що використання спільних форм навчальної роботи вносить істотні позитивні зміни у формування такого особистісного утворення, як самооцінка А. Захарова [686], I. Кон [692], та ін.). Спільна діяльність дає дитині можливість порівнювати себе з однолітками, у ній створюються умови для розвитку умінь і потреб аналізувати, доводити свою думку, оцінювати свої дії з точки зору інших.

Численні дослідження (Р. Бернс [678], Г. Ліпкіна [697], Г. Цукерман [712] та ін.) доводять, що умови для розгорнутого формування самооцінки створюються лише у школі, де учіння як основний психологічний інструмент пізнавального розвитку дитини стає предметом спеціальних дидактичних, формувальних впливів учителя, об’єктом діяльності учня. Самооцінка учня утворюється поступово під впливом двох чинників: оцінки оточення (учителі, батьки, однокласники) і порівняння результатів своєї діяльності з результатом діяльності інших людей (однокласників). Самооцінка у цьому віці за традиційних умов навчання $\epsilon$ копією оцінки педагога, iï буквальним відтворенням. 
У процесі навчання молодший учень активно опановує найпростіші форми самоконтролю: контроль за результатом або підсумковий контроль та поточний або покроковий. У результаті цілеспрямованого формування, починаючи з 2-3 класу, можуть бути розвинуті як ретроспективна (оцінка вже виконаної роботи), так і прогностична (оцінка майбутньої роботи) форми самооцінювання учнів.

Вивчення процесу формування самооцінки учнів у навчальній діяльності показало, що адекватної оцінки учнями виконаної ними роботи, усвідомлення вимог, яким вона має відповідати, можна досягти лише шляхом включення самого учня до оцінного процесу, шляхом організації його роботи над критичним аналізом і оцінюванням своєї роботи. Оцінка власних дій виводить на самокорекцію та саморегуляцію - на показники формування особистості школяра, на рефлексію, коли особистість звітує перед собою про те, що і як зроблено, формує самооцінку.

Здійснене дослідження дало змогу виявити, що структура навчальної діяльності відзначається органічним поєднанням трьох складових іiі блоків (частин). Призначення першої частини навчальної діяльності (інформаційноорієнтаційної) - входження учня у конкретну навчальну ситуацію, іiї аналіз і визначення плану наступних навчальних дій. Здійснення продуманих та запланованих дій складає другу частину навчальної діяльності - операційнодіяльнісну. Перевірка правильності здійсненого й усунення допущених помилок складають третю частину навчальної діяльності - контрольно-оцінну.

У процесі дослідження доведено, що всі частини навчальної діяльності молодших школярів за спеціально організованої роботи та створення дидактичних умов мають значний потенціал формування самооцінки.

Синтез ідей, розроблених у вітчизняній i зарубіжній психологопедагогічній науці, аналіз передового педагогічного досвіду формування самооцінки молодших школярів у навчальній діяльності дали можливість визначити дидактичні умови, за яких цей процес відбувається успішніше. Першою такою умовою нами визначено мотивацію учнів до самооиінної діяльності. 
Щоб забезпечити формування самооцінки як важливої якості особистості молодшого школяра, вчителю необхідно своєчасно приділяти увагу саме мотиваційній сфері учнів, оскільки йому набагато легше налагоджувати діловий контакт, взаєморозуміння з учнями 3 позитивним ставленням до процесу самооцінювання. У результаті такої взаємодії молодші школярі охочіше виконують вимоги вчителя, у них швидше формується пізнавальний інтерес, 3 меншими фізичними і моральними зусиллями виробляються необхідні навички й уміння самооцінювання, що породжує прагнення систематично аналізувати $\mathrm{i}$ оцінювати власні досягнення в навчальній діяльності. У підсумку вони сприймають самооцінку як важливу якість особистості, що є для людини цінністю для самоствердження в соціумі.

У процесі організації навчальної діяльності учитель, озброюючи учнів знаннями та вміннями використання критеріїв оцінної діяльності, включає учнів у систематичний і послідовний процес взаємодії з аналізу та оцінки навчальних досягнень. Це породжує у молодших школярів бажання співвідносити власні досягнення навчальної діяльності 3 досягненнями інших учнів і сприймати власні успіхи в навчальній діяльності як внесок у спільну справу. У такий спосіб формується самооцінка учнів. Отже, другою, визначеною нами дидактичною умовою формування самооцінки молодших школярів у навчальній діяльності, $\epsilon$ включення педагогом учнів до систематичного $i$ послідовного процесу самоаналізу в умовах спільної навчальної діяльності.

На основі проаналізованої теоретично-прикладної літератури, власних експериментальних досліджень ми дійшли висновку, що адекватна самооцінка $€$ результатом процесу, в якому відбувається синтез знання молодших школярів про свої можливості у навчальній діяльності, про сутність поняття «адекватна самооцінка» (когнітивний компонент), усвідомлення цінності адекватної оцінки навчальної діяльності та інтересу до самооцінювання навчальної діяльності (мотиваційно-ціннісний компонент), вміння адекватно оцінювати власні досягнення в навчальній діяльності (діяльнісно-практичний компонент). 
Отже, процес формування адекватної самооцінки навчальної діяльності у молодших школярів вимагає дотримання такої дидактичної умови як поетапність формування мотиваційно-ціннісного, когнітивного, діяльніснопрактичного компонентів самооцінки.

Встановлено, що розгляд проблеми формування самооцінки молодших школярів у навчальній діяльності органічно пов'язаний із визначальним вектором модернізації сучасної школи - спрямованості на загальний розвиток школярів у навчально-виховному процесі, на створення для учнів оптимальних можливостей в особистісному становленні, самореалізації та розкритті індивідуальних здібностей. В основу формування самооцінки покладено принцип особистісно-орієнтованого підходу до дитини, що визнає іiі унікальність, неповторність, самоцінність та принцип педагогічного оптимізму - високого рівня очікувань щодо дитини, віри в ії сили і можливості. У такий спосіб було визначено ще одну дидактичну умову: опора на традиції гуманістичної освіти, формування гуманних взаємин між учасниками навчального процесу, підтримка позитивного емоційного стану молодших школярів у процесі самооцінювання навчальної діяльності, надання своєчасної допомоги.

Для перевірки гіпотези щодо дидактичних умов формування самооцінки молодших школярів у навчальній діяльності було проведено педагогічний експеримент, у якому брали участь 441 учень, 54 учителі, 155 батьків Городецької та Родниківської загальноосвітніх шкіл I-III ступенів Уманського району Черкаської області, Уманської загальноосвітньої школи I-III ступенів №9 Черкаської області, Комунального закладу освіти «Середня загальноосвітня школа №84» Дніпропетровської міської ради Дніпропетровської області, Миколаївської загальноосвітньої школи I-III ступенів №50 імені Г.Л. Дівіної Миколаївської області.

Необхідно зазначити, що експеримент проходив у природних умовах, не порушуючи логіки та ходу навчального процесу та передбачав такі етапи: 
- проєктування - діагностика сформованості самооцінки учнів, постановка мети й завдань щодо формування самооцінки учнів;

- організація формування самооцінки - роботу над формуванням структурних компонентів самооцінки в умовах спільної навчальної діяльності: когнітивного, мотиваційно-ціннісного, діяльнісно-практичного;

- регулювання й корекція формування самооцінки - систематичний рефлексійний аналіз та своєчасна корекція результатів процесу формування самооцінки в умовах спільної навчальної діяльності.

Визначені педагогічні умови, що забезпечують повноцінне формування самооцінки молодших школярів у процесі навчання: мотивація учнів до самооцінної діяльності; включення педагогом учнів до систематичного i послідовного процесу самоаналізу в умовах навчальної діяльності; поетапність формування мотиваційно-ціннісного, когнітивного, діяльнісно-практичного компонентів самооцінки; опора на традиції гуманістичної освіти, формування гуманних взаємин між учасниками навчального процесу, підтримка позитивного емоційного стану молодших школярів у процесі самооцінювання у навчальній діяльності, надання їм своєчасної допомоги.

Для одержання інформації про рівень сформованості когнітивного, мотиваційно-ціннісного й діяльнісно-практичного компонентів самооцінки молодших школярів було проведено констатувальний етап експерименту, у якому застосовувалися три групи діагностичних завдань.

Насамперед це мотиваційно-ціннісний компонент, що містить потребу в діяльності самооцінювання та інтерес до цієї діяльності.

У процесі дослідження були визначені рівні розвитку мотиваційноціннісного компонента.

Високий рівень характеризується сформованістю в учнів стійкого інтересу до самооцінювання. Вони проявляють усвідомлену діяльнісну активність в оцінній діяльності, намагаються проявляти ініціативу й самостійність, учитель виступає в ролі партнера-консультанта. 
Середній рівень відрізняється нестійким інтересом школярів до самооцінної діяльності, відзначається активність учнів, але переважно вона залежить від вказівок учителя (наслідувальна активність), який виконує функцію організатора самооцінної діяльності учнів. Потреба в саморозвитку, інтерес до особистісних якостей спонукає до діяльності самооцінювання.

Низький рівень пов'язаний 3 короткочасним інтересом до оцінної діяльності, що має ситуативний характер, або спостерігається відсутність потреби здійснювати самооцінювання в процесі навчання, тож учні не проявляють активності (є інертними), а лише виконують вказівки вчителя. Основні мотиви поведінки - запобігання неприємностей і мотив добробуту.

Когнітивний компонент включає: рівень уявлень молодших школярів про самооцінку; наявність знань про еталони, з якими порівнюється, оцінюється діяльність і їі результати.

Спираючись на діагностичні дані ми виокремили рівні у розвитку когнітивного компонента.

Високий рівень характеризується достатньою повнотою володіння як декларованими (про те, що оцінювати), так і процедурними (про те, як оцінювати) знаннями. Учень уміє самостійно обрати еталон і критерії оцінювання, знає операційний склад оцінних дій, виявляє загальні підходи застосування оцінних умінь, критично оцінює свої можливості, проявляє прагнення до удосконалення своїх оцінних умінь.

Середній рівень відрізняється частковою або мінімальною повнотою володіння знаннями, критерії й еталони оцінювання визначаються за допомоги вчителя. Школяр знає, як оцінювати, але оцінні дії відрізняються хаотичністю, не завжди може сформулювати своє судження, надати змістовну оцінку, не завжди критично ставиться до зовнішніх оцінок.

Низький рівень характеризується мінімальною повнотою знань. Учень не орієнтується в системі еталонів і критеріїв оцінювання, не може пояснити, як оцінювати роботу або відповідь, уникає здійснення оцінювання, оскільки не здатний співвіднести об'єкт оцінювання з еталоном, не може пояснити своєї 
точки зору, завжди погоджується з будь-якими зауваженнями, не може оцінити складність завдання, цілком залежить від допомоги вчителя

Діяльнісно-практичний компонент об'єднує: володіння різними способами самооцінювання; здатність до розгорнутої, диференційованої самооцінки.

Ці ознаки слугували критеріями для визначення рівнів розвитку самооцінки молодших школярів у навчальній діяльності.

Рівні розвитку особистісних якостей розглядалися в роботах О. Леонтьєва [696], О. Савченко [706] та ін. О. Леонтьєв, наприклад, зазначав, що «розвиток усіх психологічних властивостей людини проходить послідовними етапами, на яких відбувається формування окремих ланок, що складають обов’язкові умови того, щоб утворився кінцевий механізм, що складає основи даної властивості [696, с. 51]».

У дослідженні з метою виокремлення рівнів розвитку самооцінки учнів початкових класів ми застосовували аналіз, співвідносили ці рівні.

Виокремлено також ступінь розвитку діяльнісно-практичного компонента характеризується, за нашими даними, також трьома рівнями.

Високий рівень: прийоми самооцінювання стають навичками. Діяльність і спілкування в групі має позитивну динаміку розвитку у сфері самовивчення i самооцінювання. Спостерігається спрямованість на виконання завдань творчого характеру - де можна виявити свої здібності; розвинути співпереживання i здатність ставати на позицію інших.

Середній рівень: учні початкових класів використовують навчальний матеріал для самооцінювання своїх здібностей, володіють прийомами самооцінювання, але користуються ними епізодично. Під час навчальної діяльності одержують інформацію про себе, здатні ставати на позицію інших.

Низький рівень: прийоми самооцінювання в учнів не сформовані; вони рідко порівнюють себе 3 іншими, не здатні пристати на позицію інших у діяльності на уроці. Уникають завдань творчого характеру, що дають можливість перевірити свої здібності. 
Отже, у розвитку кожного компонента було виокремлено три рівні: високий, середній, низький.

Розглядаючи сутність, структуру i функції самооцінки молодших школярів, ми виокремили й описали компоненти самооцінки як інтегральної якості особистості, що знаходяться у визначеному взаємозв’язку один з одним, водночас кожний $з$ них є самостійним.

У дослідженні з метою виокремлення рівнів розвитку самооцінки учнів початкових класів ми застосовували аналіз, співвідносили ці рівні.

Отже, у розвитку кожного компонента було виокремлено три рівні: високий, середній, низький.

Для одержання інформації про рівень сформованості мотиваційноціннісного, когнітивного і діяльнісно-практичного компонентів самооцінки молодших школярів було проведено констатувальний етап експерименту, у якому було застосовано три групи діагностичних методик.

Частину методик ми адаптували відповідно до мети нашого дослідження. Частково було використано відомі методики діагностики самооцінки [681]. Водночас нами було розроблено власні діагностичні методики - у дослідженні було використано методи спостереження за учнями в ситуаціях навчальної діяльності, анкетування вчителів, батьків та ін.

Перша група діагностичних методик була спрямована на діагностику мотиваційно-ціннісного компонента самооцінки.

У широкому розумінні, мотиви - це те, що спонукає людину до діяльності, заради чого вона відбувається. Як мотиви можуть виступати потреби особистості, іiі інтереси, емоції, установки й ідеали. Мотивація - це сукупність мотивів поведінки та діяльності.

Серед соціальних мотивів, що істотно впливають на поведінку молодших школярів, можна виокремити: мотиви, пов'язані з інтересом дітей до світу дорослих і з прагненням бути схожими на них («бути як дорослий»); мотиви, пов'язані зі встановленням і збереженням позитивних взаємин $з$ дорослими в 
сім’ї, в школі; мотиви самоствердження, особистих досягнень; змагальні мотиви (виграти, перемогти, бути кращим за інших); різні процесуальні мотиви.

Майже всі названі мотиви є проявом потреби школярів у визнанні і схваленні, у спілкуванні. Саме ці потреби і мотиви роблять школяра чутливим до оцінок педагогів і батьків, викликають бажання виконувати їхні вимоги. Мотив встановлення і збереження позитивних взаємин 3 дорослими є одним 3 провідних, що визначає соціальний розвиток дитини. Значущість цього мотиву для позитивного розвитку особистості вирішальна; він орієнтує дітей на засвоєння того, що $є$ найбільш важливим у культурі, до якої належить особистість.

Ціннісне ставлення до себе й інших людей - основа психічного і морального здоров’я, одна 3 умов успішної самореалізації, життєвого самовизначення дитини.

На уроці математики ми використовували методику, умовно названу «Шкала самооиінки».

Метою цієї методики було визначення співвідношення мотивів навчання школяра. Учням було запропоновано уважно прочитати кожне з наведених речень і закреслити відповідну цифру праворуч, залежно від того, як вони почуваються в цей момент.

Методика показала, що багато дітей на уроках відчувають внутрішнє напруження: «Я стривожений» $(88,9 \%)$; «Не впевнений у собі» $(69,8 \%)$; «Думки про уроки мене турбують» (79,7\%). Можна зробити попередній висновок про те, що провідними мотивами навчання $є$ мотиви запобігання неприємностей i очікування удачі, а не пізнавальні мотиви.

Для більш точної діагностики потреби в діяльності самооцінювання ми використали анкетування батьків і вчителів.

Мета методики «Яка вама дитина?» - виявлення рівня самостійності дітей, мотивація навчання, ролі батьків у вихованні і розвитку умінь правильно оцінювати себе і свої вчинки. Результати анкетування показали, що 66,7\% батьків вважають своїх дітей самостійними і самокритичними. 57,6\% батьків 
говорять про своїх дітей як емоційних, що виявляють співчуття і вміють радіти успіхам своїх близьких, друзів.

Мета методики «Вама дитина» полягала у виявленні індивідуальних особливостей дітей, рис характеру, інтересів, ставлення до навчання, до батьків, взаємини батьків і дітей. На жаль, аналізуючи анкети, ми з’ясували, що 10,2\% батьків не знають, які навчальні предмети подобаються їхній дитині, яке в неї захоплення; 15,3\% відзначили, що відводять мало часу на спілкування 3 дитиною через зайнятість по роботі. Багатьох батьків дані анкети змусили замислитися: «А чи добре я знаю свою дитину?».

Аналіз результатів анкетування батьків показав, що в цілому вони досить об’ єктивно поставилися до характеристики своїх дітей. Так, було відзначено, що 23,8\% першокласників не завжди чуйні і турботливі, трудяться тільки під контролем і за заохочення. Не надто високо оцінено вміння бути критичними. Дуже рідко дитина висловлює свою думку, критичні судження - $(17,1 \%)$, вороже сприймає критику - (9,2\%), байдужа до критичних зауважень - (10,8\%). Майже 49,9\% батьків указують на позитивні і негативні сторони особистості своїх дітей.

Друга група діагностичних методик була орієнтована на визначення рівня сформованості когнітивного компонента самооцінки, і була спрямована на виявлення уявлень молодших школярів про самооцінку, умінь учнів оцінити себе, свій характер, свої позитивні і негативні якості, зокрема це методика незакінчених речень, написання учнями міні-творів, самоописи дітей, бесіди, малюнок «Мій ромашковий портрет», «Я і моя тінь», «Який я?», «Еквалайзер», «Визначення шести суджень».

За застосування методики незакінчених речень учням пропонувалося закінчити такі речення: «Якби я міг ... », «На мою думку, мені заважає ...», «Я відчуваю, що ...» та ін.

Аналіз відповідей допоміг нам краще зрозуміти переживання, труднощі, зони конфліктів, особливості сприйняття «світу дорослих» та ціннісні орієнтації учнів початкових класів. 
Матеріал для дослідження ми одержували з міні-творів, які виконувалися в класі. Вибір теми залежав від того, яке завдання хотіли виконати: «Розповідь про свого однокласника», «Познайомтеся з моїм другом», «Який я?», «Який я буду через двадцять років». Аналізуючи твори, ми звертали увагу на думки учнів про інших людей, на оцінку особистісних якостей, на їхнє ставлення до описаних ситуацій.

Протягом року ми мали можливість простежити динаміку уявлень учнів про самих себе. Це слугувало одним з показників результативності формування самооцінки дітей і уміння оцінювати інших. Аналіз творів дав змогу визначити зміст, характеристики їхніх знань про себе. Здобуті результати свідчать про те, що широтою охоплення різних сторін життя і диференційованого самоопису учні відрізняються одне від одного: одні діти оцінюють широкий спектр своїх проявів - від конкретних дій («Я вмію добре малювати», «Добре вчуся в школі», «Можу допомогти подрузі зробити домашнє завдання» та ін.) до засобів самовиховання («Я міг би вчитися краще, якби не лінувався», «Я не завжди буваю охайним при виконанні письмових завдань» та ін.), творчих моментів своєї діяльності («Можу складати вірші»), інші зовсім вузько («Я учень 2-го класу»).

Під час проведення дослідницької роботи на уроці рідної мови дітям було запропоновано намалювати контур яблука, а потім «розфарбувати» його словами. Після того, як учні виконали це завдання, їм роздали альбомні аркуші 3 намальованими силуетами дитини і запропонували «змалювати себе словами»один зараз, другий аркуш 3 намальованим таким самим силуетом діти отримали наприкінці навчального року і зробили ще один опис.

Наприкінці року, по завершенні експерименту у більшості учнів другий силует містив більш повну інформацію про себе, ніж перший. Це вказує на те, що збільшився обсяг знань i уявлень молодших школярів про себе i удосконалився процес самооцінювання.

3 метою виявлення здатності дітей до самооцінювання на уроці рідної мови ми використовували методику «Мій ромашковий портрет». 
Дітям ставили таке завдання: написати своє ім'я і намалювати свій портрет-смайлик у центрі ромашки. Потім повздовж пелюсток написати все краще, що можна сказати про себе. Якщо потрібно, можна додати пелюстки.

3'ясувалося, що в 1-му класі при використанні методики «Мій ромашковий портрет» не вдалося виявити справжню самооцінку дитини. Учні вказали на якості, які їм не притаманні, «рішучий», «самостійний», «сильний», «відповідальний». Завищена самооцінка склала 69,8\% від загальної кількості учнів.

У другому класі завищеною самооцінка виявилася у 58,0\% учнів.

У третьому і четвертому класах 43,8\% і 27,8\% відповідно.

Наступним кроком для вивчення самооцінки молодших школярів була діагностична методика «Я і моя тінь». Перед учнями ставилося завдання написати свої позитивні (Я) i негативні (Тінь) якості. Для багатьох першокласників це була нерозв'язна задача. Не змогли вказати свої «негативні якості» 26,1\% дітей. Інші показники були такими: «мені важко», «не хочу», «погано вчуся» та ін.

У другому класі не вказали свої «погані риси»- 115,8\% дітей.

У третьому класі дали собі позитивні оцінки всі діти, хоча у деяких класах самооцінка виявилася неадекватною, завищеною. Не зуміли дати собі негативну оцінку тільки 7,9\% третьокласників.

У четвертому класі негативну оцінку не змогли дати $3,8 \%$ учнів.

Для виявлення ступеня розуміння сутності такого особистісного утворення як самооцінка, можливості їі розвитку в себе, ми використовували метод бесіди. Дітям пропонувалося відповісти на такі запитання:

1. Що тобі подобається в людях?

2. Які позитивні якості знаходять у тебе інші, як ти вважаєш?

3. Які позитивні якості ти відзначаєш у себе сам?

4. Які знаходиш у себе недоліки?

5. У чому тобі потрібна допомога дорослих (учителів, друзів, батьків)? 
Бесіда 3 дітьми 1-4-х класів проходила індивідуально, щоб вони почувалися невимушено, не комплексували перед іншими учнями. За допомогою цієї методики ми змогли наочно представити визначені вікові особливості в розвитку уявлень про самооцінку у молодших школярів: якщо в першому класі оцінити себе, свої якості, характер не змогли 46,9\% учнів, то у другому - 31,9\%, у третьому $-227,9 \%$, а в четвертому лише $9,9 \%$.

Аналогічна бесіда була проведена 3 учнями 3 метою з'ясування їхніх уявлення про зміст поняття «самооцінка».

Як показує аналіз отриманого матеріалу, уміння пояснити поняття, проілюструвати його на конкретному прикладі багато в чому демонструє рівень уявлень учнів про певну якість особистості: якщо в 1-му класі не знають чи не можуть пояснити зміст поняття «самооцінка» 59,8\% учнів, то в 4-му класі 4,9\%. Уявлення третьокласників уже ближче до правильного змісту поняття «самооцінка».

На цьому етапі експерименту також використовувалася методика «Визначення шести суджень». На уроці рідної мови школярам пропонувалося написати відповіді на питання «Хто я?». Відповіді групувалися за шістьма різними категоріями: «Ім'я», «Соціально-рольова категорія», «Моя фізична підготовка», «Особистісні характеристики», «Моя зовнішність», «Інші судження».

Найчастіше молодші школярі пишуть своє ім'я, прізвище - 89,8\%, основне заняття: «навчаюся у школі», «граю в комп’ютерні ігри» - 79,8\%; позитивні риси характеру - 59,9\%, позитивні і негативні риси характеру - 11,7\%: «я погано розв'язую задачі, але я добрий», «я засмучую батьків поганими оцінками, але я їх дуже люблю».

У результаті аналізу отриманих відповідей можна зробити висновок, що діти молодшого шкільного віку намагаються описати себе за допомогою зовнішніх характеристик і звертають увагу на фізичні дані, натомість для учнів третього класу важливим стає акцентування на своїх внутрішніх здібностях $\mathrm{i}$ характері взаємин з іншими людьми. 
Важливо не тільки дати визначення поняттю, але й у конкретній дидактичній ситуації зуміти оцінити себе, свої уміння, якості. 3 цією метою використовували діагностичну методику «Який я?». Дітям пропонувалося 15 «позитивних» i 10 «негативних» якостей. Їм було дане таке завдання: «Поміркуйте, які з цих якостей ви могли б віднести до себе?». Мета проведення цієї методики - дослідження уявлень молодших школярів про себе, своє ідеальне «Я», ставлення до самого себе. При виконанні завдання 89,9\% першокласників вказали тільки на свої позитивні якості (добрий, розумний, охайний та ін.), 30,2\% учнів другого класу вказали на такі якості, як хвалькуватість, грубість, лінощі та ін. Учні третіх класів були самокритичніші - 38,7\%, а четвертих класах узагалі вказали не тільки на позитивні, але й негативні якості, що склало - 56,9\%.

При використанні на уроці математики методики «Еквалайзер» дітям пропонувалося зобразити стовпчики з особистісними характеристиками. За основу була взята методика Дембо-Рубінштейна [683], адаптована до завдань нашого дослідження. Вона заснована на безпосередньому оцінюванні школярами низки особистих якостей: здоров'я, здібності, характер, авторитет серед однолітків, зовнішність, упевненість у собі. Обстежуваним пропонується на шести вертикальних стовпчиках відзначити певними позначками рівень розвитку у них цих якостей.

Обробка результатів здійснювалася за шістьма шкалами. Кожна відповідь виражалась у балах. Розміри кожної шкали - 10 клітин зошита. Відповідно до цього відповіді школярів отримують кількісну характеристику.

За підсумками цієї методики виявилося $88,8 \%$ учнів 3 високою самооцінкою, 11,2\% - 3 середньою. Учнів 3 низькою самооцінкою не виявлено.

Описана група методик дала змогу виявити уявлення молодших школярів про зміст поняття «самооцінка», про готовність самооцінювання, про вміння шукати в собі позитивне і негативне.

На початку навчання (1-й клас) когнітивний компонент самооцінки виступав як менш розвинутий у порівнянні 3 емоційно-ціннісним. Для збагачення когнітивної частини самооцінки молодшого школяра фактичними 
знаннями про себе, свої здібності, можливості, якості - особливе значення починає відігравати його власний індивідуальний досвід, включення у спільну навчальну діяльність.

Поступово (2-гі, 3-ті, 4-ті класи) у молодшого школяра складається певна структура знань про себе, про що можуть свідчити такі показники: уміння дитини оцінювати себе, аргументувати свої оцінки, оцінювати себе 3 погляду інших людей.

Третя група діагностичних методик була спрямована на діагностику діяльнісно-практичного компонента самооцінки.

При вивченні цього компонента структури самооцінки, основну увагу було спрямовано на: а) вміння молодших школярів правильно оцінювати інших у спільній роботі; б) уміння адекватно оцінювати власну діяльність, вчинки, пов’язані з проявом почуття товариства, колективізму, уміння працювати в групі; в) уміння правильно ставитися до оцінки безпосередньої діяльності, яка була визначена для них їхніми товаришами по групі (навіть якщо оцінка негативна).

Для цих цілей на уроці читання було застосовано методику під назвою «Режисер».

Учням пропонувалось ідентифікувати себе i своїх товаришів (однокласників) з героями, що діють в умовній ситуації. Завдання цієї методики полягало в тому, щоб з'ясувати, як діти оцінюють себе і своїх товаришів у конкретному виді діяльності, або яка їхня конкретна самооцінка і чим вона відрізняється від загальної. Найбільш придатним видом діяльності було обрано сюжетно-рольову гру.

Здобуті в дослідженні матеріали показали, що існують розбіжності при виборі ролей за сценарієм і можливостями, які виявляються учнем в реальній ігровій ситуації.

Діти часто переоцінюють себе, свої можливості. Так, 52,9\% опитаних вважають себе здатними виконати позитивні ролі, 47,1\% - негативні. В умовах реальної гри виявляється, що головні ролі можуть виконувати лише 41,2\%, 
негативні - 58,8\%. Це обумовлено розбіжністю в оцінці дітьми своїх ігрових й організаторських здібностей.

Можна зробити висновок про розбіжність оцінних суджень учнів, умовно поділених на два типи.

1-й тип - учні при оцінці і самооцінці якостей особистості використовують досить широке коло критеріїв, схильні до співвіднесення й узагальнення. Ці діти доброзичливі в оцінці товаришів і самокритичні в оцінці самих себе. Їхній самооцінці притаманні диференційованість, адекватність, обгрунтованість.

2-й тип - учні при оцінці і самооцінці якостей особистості, як правило, використовують вузьке коло критеріїв, виявляють при цьому суб'єктивізм у підході до їх вибору: їм притаманна критичність в оцінних судженнях, упередженість у виборі основ, опори на одиничні факти поведінки однолітка. Характерна тенденція до переоцінки особистісних якостей.

Методика «Діагностика особистісного розвитку» дала змогу вивчити здатність до розгорнутої диференційованої самооцінки молодших школярів, зрозуміти їхнє уявлення про те, якими їх бачать інші.

Здобуті за допомогою цієї діагностики результати дали змогу стверджувати, що в учнів першого класу спостерігаються істотні суперечності між уявленням про себе як про хорошого учня і необхідністю давати собі негативні характеристики. Поступово у молодших школярів відзначена суперечність згладжується і на перший план виходить нова - між умінням давати адекватні самооцінки і застосуванням цих умінь у спільній навчальній діяльності. Проведена діагностика показала високий ступінь кореляції між рівнями розвитку окремих компонентів самооцінки, що уможливило в цілому визначити іiі рівень як середній показник рівнів розвитку ії складових.

Високий рівень характеризується тим, що учень здійснює самооцінну діяльність усвідомлено (знає, навіщо оцінювати), уміє самостійно визначити об’єкт оцінювання (знає, що оцінювати), уміє самостійно здійснювати оцінювання на основі обраного еталона й критеріїв (знає, як оцінювати), вміє висловити власне судження й обгрунтувати свою точку зору: мовлення учня 
змістовне й вправне. В учня з високим рівнем сформованості оцінної діяльності добре розвинуті аналітико-синтетичні уміння (правильно визначає смисл сказаного), він вміє спостерігати, порівнювати, ставити запитання по сутті проблеми, здатна застосовувати знання не лише у звичайних, але й у нових ситуаціях, у нього розвинута самокритичність, уміння оцінити свої можливості, визначати недоліки у відповіді та їх причини, формулювати корекційні пропозиції, здатність здійснювати рефлексію процесу оцінювання. Такі школярі відрізняються високим ступенем самостійності в мисленні й поведінці.

Середній рівень характеризується тим, що учень володіє частковою повнотою знань, частіше вони уривчасті: знає, що оцінювати і як оцінювати, але не завжди вміє застосувати свої знання, вміє порівнювати зі зразком (еталоном) і відзначати різницю між ним і результатом власної діяльності, знає критерії оцінки, які здебільшого пропонуються вчителем. Школяреві важко пояснити свої оцінні дії, цілеспрямоване оцінювання він здійснює лише за вказівками вчителя, самокритичність не розвинута: частіше погоджується, ніж висловлює свою точку зору. Така дитина вміє визначити недоліки у відповіді, але не завжди може пояснити їх причини, не вміє сформулювати корекційні пропозиції, часто припускається помилок, шукаючи слова для висловлення своїх думок, мовлення недостатньо виразне, слабо проявляється самостійність мислення. Учень потребує не лише спрямовуючої допомоги, але й навчальної допомоги вчителя.

Низький рівень визначається тим, що учень уникає самооцінювання, часто в нього відсутня потреба в оцінюванні й він не знає, як його здійснювати, оскільки несформоване вміння порівнювати зі зразком (еталоном), критерії оцінювання обирає несуттєві, критичність не розвинута: не вміє оцінити власні дії ні самостійно, ні за вказівками учителя. Школяр відчуває складність при визначенні недоліків у відповіді, не здатний здійснювати рефлексію процесу оцінювання, має обмежений світогляд, дуже уривчасті, безсистемні знання, мовлення його односкладне, невиразне, в ньому багато помилок. Дитина потребує систематичної спонукальної, спрямовуючої і навчальної допомоги, але сприймає іiї з утрудненнями. 
Для визначення сутності кожного рівня ми вивчали першокласників. Результати цієї роботи стали підгрунтям для виділення найбільш типових представників кожного рівня.

Характеристика учнів з високим рівнем самооцінки: вчаться переважно на відмінно, знання міцні, систематичні. Прагнуть до виконання нестандартних, творчих завдань. Самооцінювання відбувається в діяльності, через результати, які є для них цінними. Доброзичливі до товаришів, прислухаються до їхніх зауважень і думки класу про свої здібності. Провідні мотиви - пізнавальні. Хочуть довідатися якнайбільше про все, в тому числі і про себе. Володіють прийомами самооцінки. Можуть продуктивно, зацікавлено працювати над виконанням складніших завдань. Самооцінка адекватна. Постійно прагнуть до самовдосконалення. Можуть без сторонньої допомоги ставити цілі саморозвитку.

У школярів з високим рівнем розвитку самооцінка реалістична. Вони непогано знають свої особливості. Водночас вони бачать їх не тільки в окремих сьогоденних ситуаціях, це вже досить узагальнені знання («У таких випадках я завжди так роблю..»). Діти добре знають свої можливості і тому можуть прогнозувати свої дії - що вийде, а що ні. Причини своїх невдач вони відносять на рахунок своїх власних недоліків. Їм не властива категорична самовпевненість. Говорячи про себе, вони схильні використовувати обережні вирази, типу: «я вважаю», «мені видається», «можливо, що».

До середнього рівня розвитку самооцінки ми віднесли тих учнів, у яких знання про себе все ще відображають думку навколишніх. В основу виділення й оцінки власних якостей лягають конкретні факти, окремі випадки, а перелік цих якостей невеликий. Діти не завжди розуміють свої здібності і можливості, хоча й охоче включаються в ситуації самооцінювання, більш ніж діти низького рівня, схильні до сумнівів і міркувань стосовно себе. Основні мотиви: добробут, досягнення, самопізнавання. Володіють деякими прийомами оцінювання себе, але застосовують ці знання епізодично здебільшого на прохання вчителя. У 
спілкуванні здобувають інформацію про себе, здатні сприйняти критику, ставати на позицію інших.

Характеристика учнів середнього рівня самооцінки: вчаться добре, ставлення до себе позитивне. Можуть дати характеристику своїх зовнішніх якостей, своїх здібностей. Самооцінка у них не завжди адекватна, оцінку з боку інших сприймають, але рідко враховують у своїй діяльності. На уроках ініціативні, володіють прийомами самоаналізу, використовують завдання творчого характеру для виявлення своїх здібностей. Емоційні. Процес самооцінювання супроводжується радістю, переживанням, подивом. До думок інших не байдужі. Прагнуть враховувати побажання однокласників, учителя.

Характеристика учнів з низьким рівнем самооцінки: вчаться нерівно, не виявляють прагнення до самопізнання. Емоції при розкритті своїх можливостей і здібностей виражені слабко. Уникають завдань творчого характеру, завдань на кмітливість, логіку, що дають можливість перевірити свої інтелектуальні здібності, властивості характеру. Самооцінка в учнів переважно неадекватна: завжди хочуть оцінити себе вище, не роблячи при цьому ніяких обгрунтувань. Слабко розвинена здатність до вольових зусиль у самопізнанні. Оцінки себе іншими членами колективу не сприймають і не враховують, рідко порівнюють себе з іншими. Основні мотиви поведінки - запобігання неприємностей і мотив добробуту.

изька самооцінка внаслідок того, що учні щодня чують з вуст батьків і вчителів негативні оцінки, а це є причиною того, що вони вже не вважають себе здатними ні на що. Для самого себе учень не представляє ніякої цінності, а його ставлення до товаришів можна схарактеризувати як умовно позитивне. Потреба в самооцінці у таких дітей не виражена, прийоми самооцінювання не сформовані.

Підбиваючи короткий підсумок опису рівнів розвитку самооцінки молодших школярів, слід зазначити, що якщо учні з високим рівнем аналізують свої вчинки і стосунки, то середнього - більше довіряють стороннім судженням 
про себе. Діти з низьким рівнем не думають про себе і практично нічого не знають про свої реальні якості і можливості.

У процесі нашого дослідження було розглянуто динаміку рівня розвитку самооцінки учнів експериментальних класів у порівнянні 3 даними масового досвіду (контрольні класи).

У результаті аналізу й зіставлення результатів, отриманих у ході констатувального етапу експериментальної роботи, можна визначити високий, середній і низький рівні самооцінки молодших школярів: високий рівень характеризує достатність структурної повноцінності самооцінної діяльності учнів, а середній і низький рівні - недостатню структурну повноцінність.

Табличя 1

Розподіл учнів за рівнями розвитку самооцінки

\begin{tabular}{|l|c|c|c|}
\hline \multirow{2}{*}{ Класи } & \multicolumn{3}{|c|}{ Рівні (у\%) } \\
\cline { 2 - 4 } & Високий & Середній & Низький \\
\hline Експериментальні класи & 15,6 & 43,3 & 41,1 \\
\hline Контрольні класи & 16,2 & 35,4 & 48,4 \\
\hline
\end{tabular}

Як свідчать результати констатувального експерименту, тільки 15,6\% учнів експериментальних класів та 16,2\% контрольних класів мають високий рівень сформованості самооцінки. 41,1\% учнів експериментальних і 48,4\% контрольних класів мають низький рівень сформованості самооцінки. У цілому для учнів початкових класів характерним є середній і низький рівні оволодіння самооцінкою, що свідчить про недостатній рівень їі структурної повноцінності. Здобуті дані підтверджують необхідність спеціального формування в молодших школярів умінь здійснювати самооцінну діяльність у процесі навчання.

Отже, завдання нашого дослідження полягає в тому, щоб навчити дитину в конкретних навчальних ситуаціях аналізувати свої вчинки і стосунки, ставити перед собою питання і відповідати на них, бачити i виявляти в ситуаціях дружнього спілкування якості людей і свої власні, оцінювати ці якості, 
розв’язувати конфліктні ситуації, робити самостійний моральний вибір. Тільки реальні і досить повні знання про себе дадуть дитині справжню опору в житті, допоможуть підвищити свій статус, реалізувати свої можливості, реалізуватися як особистості.

Проведена діагностика показала високий ступінь кореляції між рівнями розвитку окремих компонентів самооцінки, що уможливило в цілому визначити іiі рівень як середній показник рівнів розвитку їі складових.

У контрольних класах навчальна діяльність здійснювалася традиційно. В експериментальних формування самооцінки молодших школярів передбачало спеціально організоване їх навчання 3 детально визначеними цілями та діагностичним інструментарієм. Визначені дидактичні умови дотримувалися.

У початковий період навчання в першокласників домінує суперечність між уявленням про себе як про хорошого і необхідністю давати адекватну оцінку собі. Згодом на зміну приходить нова суперечність: між розвитком рефлексійної сфери і діяльнісно-практичною сферою учня. Виникнення цієї суперечності пов'язане $з$ тим, що протягом першого року навчання свідомість молодших школярів значно збагачується запасом уявлень про самооцінку, способи оцінювання, оцінні еталони. Учні вже можуть розповісти про себе, свої позитивні і негативні риси. За цих умов самооцінка стає обгрунтованішою й адекватнішою.

Відповідно до виділених суперечностей процес формування самооцінки було розділено на дві послідовні стадії.

На першій стадії формувального експерименту нами розв'язувалося завдання: стимулювання бажання оцінювати себе, свою діяльність на уроці, формування умінь оцінювати свою діяльність за «еталоном».

Формуванню в школярів позитивної мотивації до процесу самооцінки не тільки у навчанні, але й у повсякденному житті сприяли бесіди про сутність самооцінки, форми і способи їі здійснення, рольові ігри.

Бесіди проводилися під час уроків з опорою на їхній вітагенний досвід. Запитання добирались у такий спосіб, щоб діти могли брати активну участь в 
обговоренні. Добір інформації (оповідання, казки, історії з життя) полегшував сприймання та розуміння молодшими школярами нових повідомлень, давав змогу подивитися на відомі ситуації по-іншому.

Серед засобів цієї стадії переважало використання ситуацій, що спонукали учнів до самооцінювання. У цей період учні засвоїли «еталони», за якими можна адекватно оцінити себе, оцінні критерії. Після цього було здійснено перехід до ситуацій, що вимагають оцінити свою діяльність. Було проведено серія уроків, де використовувалось уміння дітей оцінювати себе, свою роботу на уроці.

На другій стадії формувального експерименту учні ставилися в ситуації спільної навчальної діяльності задля закріплення здобутих знань й умінь із самооцінки. Водночас включення дітей у спільну навчальну діяльність виявило потенційні можливості спільної навчальної діяльності для розвитку самооцінки. Провідним засобом на цьому етапі була організація спільної навчальної діяльності на уроках.

Групи для спільної діяльності складалися з двох (початковий етап), трьох, чотирьох дітей. Ця робота вибудовувалася на основі усвідомлення учнями користі і переваг спільної роботи в навчальному процесі, одержання радості від спілкування у процесі навчальної діяльності, стимулювання бажання оцінювати свою діяльність.

Проведена дослідно-експериментальна робота дала змогу дійти висновків, що під час спільної діяльності в учнів проявляються можливості: 1) спостерігати за діяльністю інших учнів у групі; 2) вільного спілкування; 3) співвідносити свою діяльність 3 діяльністю інших; 4) формувати потребу давати власні оцінки спільній діяльності; 5) правильно сприймати оцінки своєї діяльності іншими. У ході експерименту з'ясувалося, що діяльність, побудована в режимі кооперації, сприяє розвиткові адекватної самооцінки молодших школярів.

Формування самооцінки молодших школярів здійснювалося у практичнодіяльнісному контексті. Зміст діяльнісного блоку в процесі формування в учнів самооцінної діяльності полягав у залученні їх до активного формування самооцінки засобами різних їі видів і форм; здійснення змістовного оцінювання; 
виконання вибору еталонів, їх розроблення й корекції; вибір за пропозицією вчителя або самостійне визначення критеріїв оцінювання; модифікація критеріїв оцінки відповідно до різних навчальних предметів й оцінних ситуацій; застосування шкал переходу від оцінки до оцінки-балу, розроблення власних шкал під керівництвом учителя; здійснення рефлексії власної оцінної діяльності й себе як іï суб’єкта, засвоєння прийомів рефлексії.

В організації формувального етапу експерименту значну увагу було приділено формуванню гуманних взаємин між учасниками навчального процесу, підтримці позитивного емоційного стану молодших школярів у процесі самооцінювання навчальної діяльності, наданню своєчасної допомоги в самооцінювальній діяльності (порада, консультація, коригування).

На завершальному етапі експериментального дослідження було визначено динаміку сформованості самооцінки молодших школярів у навчальній діяльності на основі усереднених показників (табл. 1).

Таблиия 2

Динаміка сформованості самооцінки молодших школярів

\begin{tabular}{|c|c|c|c|c|}
\hline \multirow{2}{*}{ Рівні } & \multicolumn{2}{|c|}{ Експериментальні класи } & \multicolumn{2}{|c|}{ Контрольні класи } \\
\hline & $\begin{array}{l}\text { До } \\
\text { експерименту }\end{array}$ & $\begin{array}{l}\text { Після } \\
\text { експерименту }\end{array}$ & \begin{tabular}{|l} 
До \\
експерименту
\end{tabular} & $\begin{array}{l}\text { Після } \\
\text { експерименту }\end{array}$ \\
\hline Високий & $14,9 \%$ & $24,8 \%$ & $15,8 \%$ & $17,9 \%$ \\
\hline Середній & $43,2 \%$ & $60,1 \%$ & $35,3 \%$ & $37,8 \%$ \\
\hline Низький & $41,9 \%$ & $15,1 \%$ & $48,9 \%$ & $44,3 \%$ \\
\hline
\end{tabular}

Отже, формувальний етап експерименту підтвердив ефективність визначених дидактичних умов формування самооцінки молодших школярів у навчальній діяльності. В учнів експериментальних класів відбулися статистично достовірні кількісні та якісні зміни, що проявились у позитивній динаміці рівнів сформованості самооцінки. Зокрема, зменшилася кількість учнів з низьким рівнем самооцінки (з 41,9\% до 15,1\%). Натомість зросла кількість школярів 3 високим рівнем (з 14,9\% до 24,9\%). Динаміка спостерігається також у зміні кількості учнів 3 
середнім рівнем самооцінки: перед проведенням формувального експерименту їх було 43,2\%, після його завершення - 60,1\%. Такі зміни пояснюються тим, що певна кількість учнів з низького рівня перейшла на цей рівень, і певна частина учнів 3 середнього рівня досягла вищого рівня самооцінки. У контрольних класах за час проведення формувального експерименту також сталися певні зрушення, проте вони не досягають рівня статистичної значущості.

Проведене дослідження підтвердило основні положення висунутої гіпотези та дало змогу сформулювати висновки відповідно до поставлених завдань.

У процесі системного аналізу науково-педагогічних джерел з'ясовано, що проблема формування самооцінки особистості була актуальною в усі періоди розвитку вітчизняної та світової педагогічної науки.

Аналіз філософської та психолого-педагогічної літератури дав змогу розглядати самооцінку як основу процесу самоусвідомлення особистості, як показник індивідуального рівня розвитку, його особистісний аспект. Самооцінка як особистісне утворення позначається на регуляції поведінки і діяльності; як характеристика особистості, іiі центральний компонент формується за активної участі самої особистості і відображає своєрідність їі внутрішнього світу.

Проведений теоретичний аналіз дав змогу представити структуру самооцінки у вигляді трьох компонентів:

- мотиваційно-ціннісного, що характеризується позитивним ставленням до діï самооцінювання, потребою довідатися про себе, свої позитивні і негативні характеристики, прагненням досягти успіху у спільній діяльності, пізнавати себе 3 кращого боку;

- $\quad$ когнітивного, основу якого складають знання людини про себе - ситуативні чи стійкі, позитивні чи негативні, більш або менш значущі для особистості;

- діяльнісно-практичного як системи вмінь самооцінювання, що характеризується здатністю розрізняти ознаки, за якими діти оцінюють свої позитивні і негативні якості, діяльність у групі, уміння адекватно оцінити власну діяльність у групі, здатність критично ставитися до оцінки своїх умінь іншими учнями. 
На підставі здійсненого аналізу психолого-педагогічних наукових джерел було виокремлено функції самооцінки:

- мотиваційну, що забезпечує свідому, мотивовану поведінку, реалізацію обраної позиції, самореалізацію і охоплює всі види спонукань - мотиви, прагнення, ідеали, цілі, усвідомлені спонукання до діяльності;

- орієнтаційну, яка передбачає орієнтування в ситуаціях оцінювання себе, своїх можливостей, своєї діяльності в групі;

- регулятивну, що забезпечує свідому саморегуляцію своєї поведінки умовах, які вимагають докладання свідомих зусиль для оцінювання себе i виконуваної діяльності, керування собою в умовах емоційного збудження чи втоми, здатність діяти відповідно до вимог ситуації, дорослого чи дитячого колективу;

- рефлексійну, яка виявляється в умінні людини усвідомлювати те, що вона робить, й аргументувати, обгрунтовувати свою діяльність.

У дослідженні доведено потенційні можливості спільної навчальної діяльності у формуванні самооцінки молодших школярів. 3'ясовано, що спільною вважається діяльність, за якої ії завдання сприймаються як групові. Це потребує об'єднання учнів для розв'язання поставлених завдань. Іншою ознакою спільної діяльності є наявність взаємної залежності, взаємоконтролю та відповідальності.

Доведено, що використання спільних форм навчальної діяльності вносить істотні позитивні зміни у формування самооцінки, дає можливість порівнювати себе з однолітками, у ній створюються умови для колективного аналізу роботи, розвитку умінь і потреби аналізувати, доводити свою думку, оцінювати свої дії 3 погляду іншого.

Синтез ідей, розроблених у вітчизняній і зарубіжній психолого-педагогічній науці, аналіз передового педагогічного досвіду формування самооцінки молодших школярів у навчальній діяльності дали можливість визначити дидактичні умови, за яких цей процес відбувається успішніше:

- мотивація учнів до самооцінної діяльності;

- включення педагогом учнів до систематичного і послідовного процесу самоаналізу в умовах спільної навчальної діяльності; 
- поетапність формування мотиваційно-ціннісного, когнітивного, діяльнісно-практичного компонентів самооцінки;

- опора на традиції гуманістичної освіти, формування гуманних взаємин між учасниками навчального процесу, підтримка позитивного емоційного стану молодших школярів у процесі самооцінювання навчальної діяльності, надання їм своєчасної допомоги.

На підставі діагностичних даних у сформованості кожного компонента самооцінки було виділено три рівні: високий, середній, низький. Проведена діагностика показала високий ступінь кореляції між рівнями сформованості окремих компонентів самооцінки, що дало змогу в цілому визначити рівень сформованості самооцінки як середній показник рівнів сформованості іiї складових.

Здійснено експериментальну роботу, спрямовану на перевірку висунутої гіпотези, результати якої свідчать про ії ефективність.

Комплексне застосування визначених дидактичних умов уможливило одержання даних, які склали основу об'єктивно статистичного узагальнення: у результаті заключного діагностування було виявлено, що в експериментальних класах зросла кількість учнів, що мають високий рівень сформованості самооцінки ( 3 14,9\% під час констатувального етапу експерименту до $24,8 \%$ під час контрольного зрізу); зросла кількість учнів з середнім рівнем - 3 43,2\% до 60,1\%; зменшилася кількість учнів з низьким рівнем сформованості самооцінки - 3 41,9\% до $15,1 \%$.

Отже, проведене нами дослідження дає змогу стверджувати, що саме у початковій школі формується самооцінка молодших школярів. Це відбувається у взаємодії усіх учасників навчального процесу під керівництвом (і направленням дій школярів) учителя. 